\section{Красноярский алюминиевый завод: экологический фактор}

В.Г. СИБГАТУЛИН, НП «ЭКологический центр РОПР», Красноярск. E-mail: ec_ropr@mail.ru

Н.Г. ШиШАЦкий, кандидат экономических наук,

Институт экономики и организации промышленного производства СО РАН,

красноярск. E-mail: nik@ksc.krasn.ru

В статье рассматриваются факторы и параметры воздействия Красноярского алюминиевого завода на окружающую среду г. Красноярск. Показано, что, несмотря на реализацию намечаемых крупномасштабных мер по экологической модернизации, Красноярский алюминиевый завод остается и в обозримой перспективе будет оставаться крупнейшим загрязнителем Красноярска. Сделань предложения по снижению негативного экологического воздействия и повышению региональной экономической эффективности работы предприятия.

Ключевые слова: загрязнение атмосферного воздуха, экологическая модернизация, наилучшие доступные технологии, электролиз алюминия, региональная экономическая эффективность

\section{Ошибки проекта}

Решение о строительстве в районе Красноярска алюминиевого завода было принято Постановлением ЦК КПСС и Совета министров СССР от 5 июля 1955 г. Проектная мощность предприятия была определена в размере 400 тыс. т, при этом половину алюминия-сырца предполагалось направлять на завод алюминиевого проката. В качестве производственной площадки для алюминиевого завода был выбран участок в 14 км к северо-востоку от Красноярска, а прокатного - район деревни Коркино на окраине города.

В июне 1964 г. введен в эксплуатацию 1-й пусковой комплекс Красноярского алюминиевого завода, на проектную мощность он вышел в 1982 г. В последующие годы проектные объемы неоднократно повышались до 850 тыс. т алюминия в год.

Красноярский прокатный завод (ныне Красноярский металлургический завод - КраМЗ), ориентированный на глубокую переработку первичного алюминия, так и не был по-настоящему интегрирован в единый производственный комплекс с алюминиевым заводом. Из-за отставания ввода мощностей прокатного производства (созданы мощности по выпуску лишь 200 тыс. т проката, да и те сегодня используются только на 50-60\%) полностью нарушилась внутренняя и внешняя кооперация двух предприятий, ради которой в 1956-1965 гг. алюминиевый завод, проектные мощности которого были удвоены, построен в черте Красноярска.

Серьезной ошибкой было предусмотренное проектом использование устаревшей и экологически «грязной» технологии электролиза алюминия в 1920-х гг. на основе самообжигающихся угольных анодов Содерберга. Эта технология, наряду с низкой производительностью, значительными энергозатратами, наносит огромный вред экологии, генерируя крайне вредные вещества оксида углерода, смолистые соединения, в том числе канцерогенные (бензапирен, бензантрацен и др.).

Производители алюминия в большинстве стран мира отказались от использования данной технологии. Начиная с 1990-х годов вводимые в эксплуатацию заводы и в России, и в мире оборудуются только электролизерами с обожженными анодами. Сегодня в мире (без России) более $85 \%$ первичного алюминия производится с использованием предварительно обожженных анодов (технология Эру-Холла), и лишь менее 15\% - с использованием самообжигающихся. Так, например, в Австралии с использованием технологии обожженных анодов производится 100\% алюминия, в США и Канаде $-77 \%$, в Западной Европе $-87 \%{ }^{1}$. Последним масштабную технологическую модернизацию своих алюминиевых предприятий в 2000-х годах провел Китай ${ }^{2}$. И только в России использование технологии самообжигающихся анодов сохраняет свою ведущую роль - более $80 \%$ алюминия «РУСАЛа» производится на электролизерах с анодами Содерберга.

Сверхвысокая концентрация производственных мощностей КрАЗа, работающих с использованием чрезвычайно опасной с экологической точки зрения технологии, обусловила недопустимо высокий уровень загрязнения воздушного бассейна Красноярска и его окрестностей вредными загрязняющими веществами: неорганической пылью, плохо растворимыми фторидами, смолистыми веществами (полициклическими ароматическими углеводородами, в том числе - бензапиреном), фтористым водородом, окисью

\footnotetext{
Мировой рынок алюминия [Эл. pecypc]. URL: http://www.webeconomy.ru/index.php?p age=cat\&newsid=835\&type=news (дата обращения: 22.01.2018).

2 «Русал» против Китая: почему производители из Поднебесной теснят других производителей [Эл. pecypc]. URL: http://www.forbes.ru/kompanii/341285-rusal-vproigryshe-pochemu-kitayskie-proizvoditeli-konkurentnee-rossiyskoy-kompanii (дата обращения: 22.01.2018).
} 
углерода, сернистым ангидридом, хлористым водородом, хлором и др. В 1988 г. годовые выбросы загрязняющих веществ в атмосферу города составили 123 тыс. т (47,7\% общегородских выбросов стационарных источников промышленных предприятий). Эти выбросы более чем в два раза превысили объемы предельно допустимых (ПДВ), установленные письмом от 06.04.1988 г. № 011В-243 Красноярского территориального управления по гидрометеорологии и контролю природной среды и решением исполкома Красноярского крайсовета от 24.02.1988 г. № 74-п «О серьезных недостатках по охране окружающей среды на КрАЗе» (табл. 1).

\section{Таблица 1. Динамика выбросов загрязняющих веществ}

Красноярского алюминиевого завода в атмосферу в 1985 г. и 1988 г., т/год

\begin{tabular}{|l|c|c|c|c|}
\hline \multicolumn{1}{|c|}{ Вещество } & $\mathbf{1 9 8 5}$ & $\mathbf{1 9 8 8}$ & $\begin{array}{c}\text { ПдВ } \\
\text { (письмо Крас- } \\
\text { гидромета) }\end{array}$ & $\begin{array}{c}\text { Превышение фактических } \\
\text { выбросов 1988 г. по отно- } \\
\text { шению к ПдВ, раз }\end{array}$ \\
\hline Всего & 182178,3 & 122997,1 & 56508,0 & 2,2 \\
\hline В том числе: & & & & 5,0 \\
\hline неорганическая пыль & 19977,6 & 15248,6 & 3066,0 & 8,3 \\
\hline $\begin{array}{l}\text { плохо растворимые } \\
\text { фториды }\end{array}$ & 4019,8 & 3245,2 & 390,0 & 12,1 \\
\hline фтористый водород & 2851,2 & 2295,8 & 190,0 & 67,5 \\
\hline смолистые вещества & 6088,2 & 5131,4 & 76,0 & 131,0 \\
\hline бензапирен & $4,5\left(^{*}\right)$ & $3,8\left(^{*}\right)$ & $0,029\left(^{\star \star}\right)$ & \\
\hline
\end{tabular}

Источник: [Экологический паспорт..., 1989].

\section{Примечания к табл. 1-2:}

* Выбросы бензапирена определены расчетным путем (0,075\% от смолистых веществ, согласно разъяснениям ВАМИ).

** ПДВ на бензапирен взяты ориентировочно из ТЭО строительства завода обожженных анодов для обеспечения перевода КрАЗа на электролизеры с обожженными анодами, т. IY. С. 15-16, ВАМИ, 1988 г.

Для достижения установленных нормативов ПДВ в тот период (1988 г.) требовалось снизить текущие выбросы по бензапирену в 131 раз, по смолистым веществам - в 67, по фтористому водороду - в 12, по плохо растворимым фторидам - в восемь, по окиси углерода - в два раза.

По результатам наблюдений в 1983-1984 гг. в микрорайоне Красноярска Зеленая роща зарегистрированы максимальные разовые концентрации бензапирена, превышающие санитарные нормы в 383 и 380 раз соответственно. Согласно расчетам, возможный уровень загрязнения атмосферы Красноярска бензапиреном распределялся следующим образом: в Академгородке - 17,5 ПДК, в Центральном и Кировском районах - 30 ПДК, на восточной границе микрорайона Зеленая роща - около 200 ПДК, в деревне Коркино и поселке Индустриальном - свыше 400 ПДК.

Загрязнение атмосферного воздуха выбросами КрАЗа особенно губительно в условиях Красноярска, расположенного в котловине. Это способствует образованию местной циркуляции и возможному накоплению примесей в нижних слоях атмосферы. Велика повторяемость метеорологических факторов (штиль или слабый ветер, инверсии, туманы), способствующих возникновению высоких и экстремально высоких уровней загрязнения атмосферного воздуха. Ухудшению экологической обстановки города способствует также резкое изменение гидрологического режима реки Енисей в связи со строительством плотины Красноярской ГЭС, из-за чего в 2-3 раза увеличилось число туманов, повысилась влажность воздуха, вызвавшие ухудшение рассеивающей способности атмосферы.

«Перемещение КрАЗа на существующую площадку из д. Кубеково, где первоначально планировалось его размещение; необоснованное увеличение его мощностей в 2 раза; высокая концентрация электролизного производства, которая в несколько раз превосходит наиболее мощные зарубежные аналоги; использование устаревших и неэффективных технологических решений электролиза алюминия с использованием самообжигающихся анодов Содерберга, а также несовершенной системы очистки отходящих газов следует считать крупной экологической ошибкой». Такой вывод содержится в Экологическом паспорте Красноярского алюминиевого завода - фундаментальной работе, выполненной большим авторским коллективом в Красноярском научном центре СО АН СССР в 1989 г.

Острая ситуация с экологической обстановкой в г. Красноярске вынудила высшие органы СССР прибегнуть к радикальным мерам по технологической модернизации предприятия. В 1985 г. было принято Постановление Совмина СССР «О дополнительных мерах по предотвращению загрязнения атмосферного воздуха и водных объектов в районе г. Красноярска», в котором содержалось указание: «Министерству цветной металлургии СССР разработать в 1986 г. и осуществить в 1987-1990 гг. комплекс подготовительных работ по поэтапному переводу, начиная с 1991 г., Красноярского алюминиевого завода на технологию производства алюминия с использованием обожженных анодов». 
Подготовка к реализации соответствующей программы активно велась в конце 1980-х - начале 1990-х гг., однако задуманную модернизацию не довели до конца.

Все это привело к тому, что в конце 1980-х годов поднимался вопрос о сокращении производства, вплоть до закрытия завода. КрАЗ был самым непопулярным предприятием в Красноярске. Общественное мнение относило в основном на его счет неблагополучное экологическое состояние в городе.

С 1991 г. над Красноярским алюминиевым заводом контроль устанавливает швейцарская трейдинговая компания Marc Rich. B 1993 г. начинается приватизация, и в течение следующих двух лет его акционером становится британская Trans World Group (TWG).

В 1994 г. по договоренности с генеральным директором КрАЗа контроль над предприятием установил местный бизнесмен А. Быков (стал членом совета директоров завода и получил 10\% его акций). После этого Быков «вычеркнул из реестра» $17 \%$ акций завода, принадлежавших TWG. В прессе этот конфликт Быкова с другими акционерами КрАЗ получил название «первой алюминиевой войны».

В сентябре 1997 г. Быков стал вице-президентом банка «Российский кредит» - крупнейшего акционера завода. К 1998 г. ему принадлежало 28\% акций завода. Войдя в руководство КрАЗа, Быков распространил своё влияние на другие предприятия Красноярска. Для этого он создал финансово-промышленную группу «ТАНАКО», в которую вошли «Красноярскэнерго», Красноярская ГЭС, Ачинский глинозёмный комбинат и другие крупнейшие предприятия края.

В 1999 г. против А. Быкова было возбуждено уголовное дело, в 2000 г. совет директоров КрАЗа принял решение о сложении с него полномочий председателя совета директоров, а КрАЗ вошел в состав компании «Русский алюминий» (Русал) $)^{3}$.

1990-е годы характеризовались для Красноярского алюминиевого завода поиском таких организационных структур и форм рыночных отношений, которые позволили бы предприятию удержаться на плаву, завоевать соответствующие сегменты мирового и российского рынка, сохранить производственный потенциал. И хотя в этих условиях было не до системных технологических преобразований, удалось реализовать достаточно крупные технологические проекты. К 1996 г. на КрАЗе немецкой фирмой Kaiser были переведены два корпуса (из 25) на технологию с использованием обожженных анодов, это обошлось примерно в 3,5-5,0 тыс. долл. на 1 т алюминия. В результате мер по модернизации процесса электролиза и газоочистки, а также ужесточения технологической дисциплинь экологические показатели завода значительно улучшились. Однако

${ }_{3}$ Красноярский алюминиевый завод //Википедия [Эл. ресурc]. URL: https://ru.wikipedia.org/wiki/Красноярский алюминиевый завод (дата обращения: 22.01.2018); Быков Анатолий Петрович //Википедия [Эл. ресурc]. URL: https://ru.wikipedia.org/wiki/Быков Анатолий_Петрович (дата обращения: 22.01.2018). выбросы опасных загрязняющих веществ продолжали превышать установленные пределы во много раз (табл. 2).

Таблица 2. Выбросы загрязняющих веществ Красноярского алюминиевого завода в атмосферу в 1995 г., т/год

\begin{tabular}{|l|c|c|c|}
\hline \multicolumn{1}{|c|}{ Вещество } & $\mathbf{1 9 9 5}$ & $\begin{array}{c}\text { ПдВ } \\
\text { (письмо Крас- } \\
\text { гидромета) }\end{array}$ & $\begin{array}{c}\text { Превышение фактических } \\
\text { выбросов по отношению к ПдВ, } \\
\text { раз }\end{array}$ \\
\hline Всего & 107365,0 & 56508,0 & 1,9 \\
\hline В том числе: & & & 2,74 \\
\hline пыль неорганическая & 8413,0 & 3066,0 & 5,0 \\
\hline плохо растворимые фториды & 1934,0 & 390,0 & 8,7 \\
\hline фтористый водород & 1649,0 & 190,0 & 21,5 \\
\hline смолистые вещества & 1634,0 & 76,0 & 42,4 \\
\hline бензапирен & $1,23\left(^{*}\right)$ & $0,029\left(^{* \star}\right)$ & \\
\hline
\end{tabular}

Источник: [Алюминиевая промышленность.., 1997. С. 43].

\section{Экологическая модернизация КрАЗа в составе «РУСАЛа"}

Принципиальная позиция «РУСАЛа» в отношении модернизации КрАЗа заключается в попытках использовать резервы совершенствования технологии самообжигающихся анодов с последовательным отказом от перехода на технологию обожженных анодов. По мнению технического директора компании В. Манна, «перевод уже существующего предприятия на такую технологиюпроцесс очень длительный и крайне затратный. Мы разрабатывали два технико-экономических обоснования и выяснили: чтобы перевести такой гигант, как КрАЗ, на технологию с обожженными анодами, необходима сумма от 2,5 до 3 млрд долл. Кроме того, это неизбежно связано с остановкой части производства.

Я считаю, что это нереально. Прецеденты перевода алюминиевых заводов с технологии Содерберга на технологию обожженных анодов можно по пальцам пересчитать, и заводы эти очень маленькие. Проще построить новый завод, а старый закрыть... ${ }^{4}$

Экологическая модернизация КрАЗа, в соответствии с программой «РУСАЛа», рассчитанная на 2004-2021 гг., включала два этапа. На первом основные усилия были сосредоточены

${ }^{4}$ Манн В. По Богучанскому и Красноярскому алюминиевым заводам приняты экономически взвешенные решения [Эл. ресурc]. URL: http://www.mkkras.ru/news/print/ id-2826/ (дата обращения: 22.01.2018). 
на повышении эффективности традиционной технологии. Общая сумма затрат составила 305 млн долл., однако экологическую направленность имели лишь 79 млн долл., потраченные на строительство современных газоочистных систем, а 74\% пошли на увеличение производственных мощностей путем добавления дополнительных электролизеров в существующие цехи и усиление силы тока. За счёт этого мероприятия годовое производство алюминия на КрАЗе увеличилось с 800 тыс. т до 1 млн т5.

Модернизация в рамках первого этапа привела (по утверждениям «РУСАЛа») к снижению удельных выбросов вредных веществ на тонну произведенного алюминия. Однако с учетом роста производственной мощности и объемов электролиза алюминия, фактическое валовое снижение оказалось намного ниже требуемого.

Осознавая неудовлетворительные результаты первого этапа модернизации и тупиковость попыток вдохнуть новую жизнь в традиционную технологию, «РУСАЛ» переходит к новой стратегии - созданию и внедрению на КрАЗе технологии «Экологически приемлемый Содерберг».

«Мы поставили цель - добиться с помощью технологии “ЭКологичный Содерберг (ЭкоСодерберг)” тех же результатов, что и с обожженными анодами. И уже многого добились. Технология “ЭкоСодерберг” дает вторую жизнь заводам с технологией Содерберга, а это основная доля нашего производства. Перевод электролизеров на "ЭкоСодерберг” мы начали в январе 2015 г. Первым предприятием, где начала внедряться эта технология, стал КрАЗ, и на сегодня в Красноярске модернизировано уже 637 электролизеров. Процедура перевода действующих электролизеров на “ЭэкоСодерберг" совмещается с проведением капитальных ремонтов - это оправданно и технологически, и с точки зрения затрат» ${ }^{6}$.

Данная стратегия легла в основу второго этапа экологической модернизации КрАЗа (2011-2021 гг.). Этот этап еще не закончен (на начало 2018 г. на новую технологию переведено около 60\% электролизеров КрАЗа). Полная реализация программы предполагает 100\%-й перевод на усовершенствованную технологию

${ }_{5}^{5}$ Можно ли похоронный марш переделать в победный?// Красноярский рабочий 19.03.2010 [Эл. pecypc]. URL: http://www.krasrab.com/archive/2010/03/19/01/view_article (дата обращения: 22.01.2018).

${ }^{6}$ Манн $B$. Новые технологии радикально изменят облик алюминиевой индустрии [Эл. pecypc]. URL: http://www.dela.ru/interview/214636/ (дата обращения: 22.01.2018)
«ЭкоСодерберг» всех электролизеров, использующих самообжигающиеся аноды.

Ключевое преимущество новой технологии заключается в том, что вместо традиционной анодной массы используется коллоидный анод. Он содержит низкое количество пека, который является основным источником выбросов смолистых веществ. Усовершенствованная конструкция электролизера обеспечивает его высокую герметичность, что дополнительно снижает количество выбросов.

По заявлению пресс-службы «РУСАЛ-Красноярск», после внедрения новой технологии завод снизит выброс фторидов в 3,5 раза -с 2,5-3,5 до 0,72 кг/т; пыли в 3,5 раза-с 11-16,9 до 1,83,6 кг/т; диоксида серы - в 1,5-2 раза с 1,5-2,3 до не более 1,0 кг/т; смолистых веществ - в 1,5 раза - с 1,5-2,24 до 0,89-1,38 кг/ T $^{7}$.

На предприятии не скрывают, что перечисленные меры позволят еще как минимум 20 лет эксплуатировать электролизеры, работающие на технологии Содерберга, а сама модернизация обойдется в пять раз дешевле, чем полный переход КрАЗа на обожженные аноды.

Действительно, удельные суммарные выбросы загрязняющих веществ, а также отдельных токсичных ингредиентов (фторидов, диокида серы, сернистого ангидрида и др.) при переводе КрАЗа на технологию «ЭкоСодерберг» практически выйдут на уровень технологии с предварительно обожженными анодами (табл. 3).

Однако необходимо учитывать следующие факторы, сохраняющие недопустимую экологическую опасность производственной деятельности КрАЗа даже в модернизированном варианте.

1. Сверхмощности предприятия (1 млн т алюминия в год) в пять раз превышают среднюю мощность алюминиевых заводов в мире и в 2-3 раза-мощность самых крупных из них. Это приводит к тому, что даже при сопоставимых (приемлемых) удельных показателях выбросов на 1 т алюминия их суммарный (валовой) объем кратно превосходит воздействие типовых предприятий алюминиевой промышленности на окружающую среду.

Внедрение проекта «Экологически приемлемая технология Содерберга»//AO «Русал Красноярск». Презентация, июль 2017 г. [Эл. pecypc]. URL: http://tehne.com/assets/i/upload/ event/RUSAL-Krasnoiarsk.pdf (дата обращения: 22.01.2018); Федеральное агентство по техническому регулированию и метрологии. Информационно-технический справочник по наилучшим доступным технологиям. ИТС 11-2016. Производство алюминия. М.: Бюро НДТ, 2016. 146 с.. 
Таблица 3. Сравнительные экологические характеристики технологий производства алюминия с обожженными анодами и «ЭкоСодерберг»

\begin{tabular}{|c|c|c|c|c|c|}
\hline \multirow[b]{2}{*}{ Технология электролиза } & \multicolumn{5}{|c|}{$\mathrm{Kr} / \mathrm{TAl}$} \\
\hline & $\begin{array}{c}\text { Фтористый } \\
\text { водород }\end{array}$ & $\begin{array}{l}\text { Твердые } \\
\text { фториды }\end{array}$ & $\begin{array}{c}\text { Диоксид } \\
\text { серы }\end{array}$ & $\begin{array}{l}\text { Пыль } \\
\text { общая }\end{array}$ & $\begin{array}{c}\text { Оксид } \\
\text { углерода }\end{array}$ \\
\hline $\begin{array}{l}\text { С обожженными анодами второго } \\
\text { поколения (мощностью } 300 \mathrm{kA} \\
\text { и выше) }\end{array}$ & $\leq 0,23$ & $\leq 0,37$ & $9,2-13,8\left(^{*}\right)$ & $2,2-2,7$ & До 100 \\
\hline $\begin{array}{l}\text { С верхним подводом тока к аноду } \\
\text { по технологии «ЭкоСодерберг» }\end{array}$ & 0,38 & 0,34 & $\leq 1,0\left(^{\star \star}\right)$ & $1,8-3,6$ & До 70 \\
\hline $\begin{array}{l}\text { Превышение выбросов при техно- } \\
\text { логии «ЭкоСодерберг» по отноше- } \\
\text { нию к технологии с обожженными } \\
\text { анодами }\end{array}$ & в 1,65 раза & $\begin{array}{l}\text { соответст- } \\
\text { вует }\end{array}$ & ниже & $\begin{array}{l}\text { соответ- } \\
\text { ствует }\end{array}$ & ниже \\
\hline
\end{tabular}

Источник: [Федеральное агентство.., 2016].

Примечания: * содержание серы в анодах - до 2\%; ** "сухая» ГОУ со II ступенью

мокрой доочистки. При использовании только первой, «сухой» ступени ГОУ количество $\mathrm{SO}_{2}$ зависит от содержания серы в анодной массе.

2. Технология «ЭкоСодерберг» не решает проблему выбросов смолистых веществ, в том числе наиболее опасного канцерогенного бензапирена. Последний опасен даже при малой концентрации, так как обладает свойством биоаккумуляции и оказывает мутагенное действие (табл. 4).

Таблица 4. Динамика выбросов смолистых веществ и бензапирена КрАЗом в 1988-2021 гг. и их соотношение с ПДВ, т

\begin{tabular}{|l|c|c|c|c|c|}
\hline \multicolumn{1}{|c|}{ Вещество } & $\mathbf{1 9 8 8}$ & $\mathbf{1 9 9 5}$ & $\mathbf{2 0 2 1}$ & $\begin{array}{c}\text { ПдВ } \\
\mathbf{1 9 8 8} \text { г. }\end{array}$ & $\begin{array}{c}\text { Превышение в 2021 г. над } \\
\text { ПдВ 1988 г., раз }\end{array}$ \\
\hline Смолистые вещества & 5131,4 & 1634,0 & $900-1400$ & 76 & $11,8-18,4$ \\
\hline в том числе бензапирен & 3,8 & 1,23 & до 0,5 & 0,029 & До 17,2 \\
\hline
\end{tabular}
Примечания. Фактические объемы выбросы смолистых веществ взяты из [Алюминиевая промышленность.., 1997]; прогнозные объемы выбросов смолистых взщты из ГФедеральное агентство.. 2016]; выбросы бензапирена оценены на КстА планов КрАЗа по переходу на технологию “ЭкоСодерберг»; ПдВ 1988 г. [Экологический паспорт.., 1989].

Превышение предельных норм выбросов КрАЗом при использовании технологии «ЭкоСодерберг» будет составлять по смолистым веществам 12-18 раз, по бензапирену - до 17 раз, а концентрация бензапирена в эпицентре выбросов КрАЗа будет превышать в 1000 раз среднесуточные ПДК, утвержденные Минздравом РФ для населенных пунктов ${ }^{8}$.

Г Гигиенические нормативы ГН 2.1.6.1338-03 Минздрава РФ [Эл. ресурс]. URL: http://gostbank.metaltorg.ru/data/norms new/gn/10.pdf (дата обращения: 22.01.2018).
3. Беспрецедентное размещение КрАЗа в черте города-миллионника с повышенным потенциалом загрязнения атмосферного воздуха (в Красноярске, помимо КрАЗа, есть другие масштабные загрязнители атмосферного воздуха, город входит в число российских и мировых лидеров по уровню экологической напряженности) резко усиливает негативное воздействие токсических загрязняющих веществ, сопровождающее производственную деятельность предприятия.

Анализ атмосферного воздуха показывает, что в крупных промышленных центрах региона (в том числе в Красноярске) сохраняется повышенный риск развития злокачественных новообразований, высока вероятность развития болезней органов дыхания, иммунной системы, болезней крови, глаз, обусловленных воздействием загрязненного атмосферного воздуха (табл. 5).

Таблица 5. Канцерогенные и неканцерогенные риски в связи с загрязнением атмосферного воздуха в городах Красноярского края в 2016 г.

\begin{tabular}{|c|c|c|}
\hline Территория & $\begin{array}{l}\text { Суммарный канце- } \\
\text { рогенный индиви- } \\
\text { дуальный риск }\end{array}$ & $\begin{array}{l}\text { Суммарные неканцерогенные риски по критиче- } \\
\text { ским органам, системам (максимальное значение } \\
\text { индекса опасности) }\end{array}$ \\
\hline Ачинск ${ }^{1}$ & $2,4 \mathrm{E}-04$ & $\begin{array}{l}12,75 \text { (органы дыхания), 8,47 (иммунитет), 6,1 (глаза), } \\
\text { 3,17 (кровь), 3,9 (смертность), 1,1 (ССС) }\end{array}$ \\
\hline Канск ${ }^{1}$ & $2,2 \mathrm{E}-06$ & 1,49 (органы дыхания), 1,12 (кровь) \\
\hline Красноярск ${ }^{1}$ & $3,55 \mathrm{E}-04$ & $\begin{array}{l}\text { 26,4 (органыдыхания), 57,5 (иммунитет), 17,4 (смертность), } \\
\text { 8,0 (развитие), 2,4 (кровь), 6,2 (глаза), 8,49 (ССС) }\end{array}$ \\
\hline Лесосибирск ${ }^{1}$ & $1,7 \mathrm{E}-04$ & $\begin{array}{l}\text { 8,9 (органы дыхания), 10,7 (иммунитет), 4,3 (глаза), } \\
\text { 3,2 (смертность), 1,4 (кровь), 1,1 (цНС), 1,1 (ССС) }\end{array}$ \\
\hline Минусинск ${ }^{1}$ & $1,1 \mathrm{E}-04$ & $\begin{array}{l}\text { 11,4 (иммунитет), 5,1 (органы дыхания), 2,4 (глаза), } \\
\text { 1,5 (кровь), 1,3 (смертность) }\end{array}$ \\
\hline Назарово $^{1}$ & $6,8 \mathrm{E}-05$ & 4,9 (иммунитет), 3,8 (органыдыхания), 1,6 (глаза), 1,2 (кровь) \\
\hline Норильск ${ }^{2}$ & $9,08 \mathrm{E}-04$ & $\begin{array}{l}241,1 \text { (органы дыхания), 55,0 (кровь), 44,7 (смертность), } \\
2,1 \text { (ЦНС), } 1,7 \text { (ССС), 1,5(развитие, репродуктивная система) }\end{array}$ \\
\hline Енисейск² & $1,30 \mathrm{E}-06$ & 1,28 (развитие), 1,17 (иммунитет) \\
\hline $\begin{array}{l}\text { Березовский } \\
\text { район }\end{array}$ & - & 2,1 (органыдыхания), 1,4 (смертность), 1,31 (ССС, развитие) \\
\hline $\begin{array}{l}\text { Емельяновский } \\
\text { район }^{3}\end{array}$ & - & 2,14 (органыдыхания), 1,6 (смертность), 1,27 (ССС, развитие) \\
\hline
\end{tabular}

Источник: [Государственный доклад.., 2017].

Примечания. Риски рассчитаны по результатам исследований: 1 - ФГБУ «Среднесибирское УГМС»; 2 - учреждений Роспотребнадзора; 3 - КГБУ «Центр реализации мероприятий по природопользованию и охране окружающей среды Красноярского края". ССС - сердечно-сосудистая система; ЦНС - центральная нервная система. 
При сохранении сложившегося уровня загрязнения атмосферного воздуха канцерогенами на протяжении предстоящих 70 лет, шанс заболеть раком у жителей г. Красноярск в 3,5 раза превышает верхнюю границу приемлемого риска для условий населенных мест (1,0E-04). Повышенный канцерогенный риск в Красноярске определяют такие загрязнители атмосферного воздуха, как формальдегид и бензол.

В условиях суммарного действия загрязняющих химических веществ среди жителей высока вероятность развития заболеваний органов дыхательной и иммунной систем, болезней глаз, заболеваний крови, нарушений процессов развития организма»9.

\section{Что дальше?}

КрАЗ за свою более чем 50-летнюю историю прошел большой путь, связанный с масштабными технологическими модернизациями. В результате осуществления крупных инвестиционных проектов, внедрения целого ряда инновационных и высокотехнологичных мероприятий и проектов удалось значительно улучшить параметры экологической эффективности завода. Однако тяжелый груз заложенных в изначальном проекте ошибок оказался столь велик, что вопрос о дальнейшей судьбе предприятия остается на повестке дня.

Призывы и предложения по ограничению масштабов производственной деятельности КрАЗа, вплоть до его полного закрытия и вывода из города, раздаются со стороны как СМИ и общественных экологических организаций, так и экспертного сообщества. Такие настроения усиливаются недовольством в связи с расширяющимся режимом «черного неба» .

Приведем ряд высказываний.

«Ночью 10 февраля вышел на балкон: ни уличных фонарей, ни земли, ни неба, ни соседних зданий было не разглядеть. Но отлично виделось то, что осталось вместо воздуха, пылевая химическая масса шевелилась, колебалась под слабым ветром, шла волнами.

Что тут бесконечно из года в год обсуждать - непонятно. Стратегических мер может быть всего две - потому что Красноярск травят из двух источников. По вкладу это: а) Красноярский алюминиевый завод (КрАЗ), б) угольные ТЭЦ. Активы Дерипаски и Мельниченко

9 Государственный доклад «О состоянии санитарно- эпидемиологического благополучия населения в Красноярском крае в 2016 году», Управление Федеральной службы по надзору в сфере защиты прав потребителей и благополучия человека по Красноярскому краю, 2017. 307 с. [Эл. ресурс]. URL: http://24.rospotrebnadzor.ru/usertags/104 (дата обращения: 22.01.2018). соответственно. Режим черного неба - это или ветер с востока, т.е. с КрАЗа, или штиль когда выбросы скапливаются в городской котловине.

КрАЗ необходимо закрыть. Или вынести из города. Или снизить производство до проектной мощности и коренным образом модернизировать. Технологий полно. Они всем специалистам известны, только красноярское начальство не в курсе» ${ }^{10}$ (рисунок).

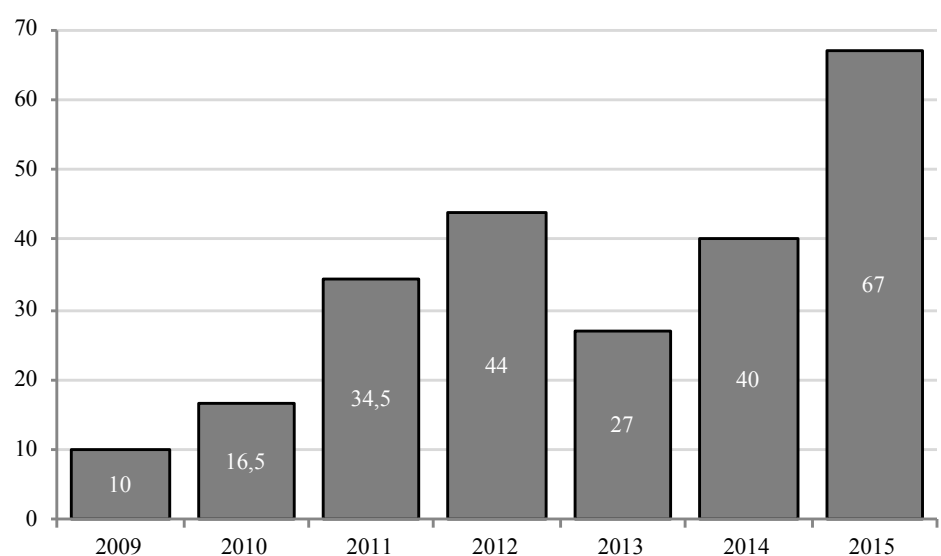

Динамика количества дней с неблагоприятными метеоусловиями (НМУ), характеризующихся особо высокой концентрацией рассеивания вредных примесей, в Красноярске в 2009-2015 гг.

Из обращения жителей Красноярска (Резолюция митинга «За чистое небо». Принято единогласно на митинге гражданами в количестве 1500-2000 человек), г. Красноярск, 18 марта 2017 г.

«Президенту Российской Федерации В.В. Путину,

Председателю Правительства Российской Федерации Д.А. Медведеву,

Депутатам Совета Федерации и Государственной думы РФ

Мы, жители Красноярска, устали жить под “черным небом". Мы устали постоянно дышать загрязненным воздухом, задыхаться, болеть и тревожиться за здоровье - своё и своих близких. Мы обращаемся ко всем ветвям и уровням власти и требуем принять меры для решения экологических проблем Красноярска

Требуем...

5. Перенести мощности завода КрАЗ за пределы Красноярска или снизить его валовые выбросы на 50\% к 2022 г. Основная цель этого пункта: снижение выбросов алюминиевого производства. Пути достижения этой цели могут варьироваться:

перенести часть мощностей на другой завод - «РУСАЛ»;

сократить выработку продукции в два раза.

${ }^{10}$ Тарасов A. Режим черного неба //Новая газета. 2017. 13фев. [Эл. ресурс]. URL: https://www.novayagazeta.ru/articles/2017/02/13/71484 (дата обрашения: 22.01.2018) 
Реализация: до 1 января 2022 г. Промежуточные результаты: 1 января каждого года»"11. На публичных слушаниях в Законодательном собрании Красноярского края по вопросу "Об экологической ситуации в городе Красноярске, неотложных и стратегических мерах по ее улучшению», состоявшихся в апреле 2016 г. предложения по поэтапному (до 750 тыс.т к 2020 г., до 400 тыс. т к 2030 г.) сокращению мощностей КрАЗа и полному закрытию предприятия к 2035 г. звучали в выступлениях Красноярского краевого общественного движения Красноярский экологический фронт, Экологического центра РОПР. Однако в рекомендациях слушаний эти предложения не нашли своего отражения ${ }^{12}$.

Рассмотрим основные аргументы против поэтапного сокращения мощностей и вывода КрАЗа за пределы города.

Аргумент 1. КрАЗ не является главным загрязнителем атмосферного воздуха в городе. Его удельный вес в суммарных выбросах загрязняющих веществ промышленных предприятий, автотранспорта и коммунальной сферы за последние годы снизился. Если в конце 1980-х годов доля КрАЗа в общих загрязнениях города достигала $50 \%$, то сегодня она (по разным оценкам) уменьшилась до $23-27 \%{ }^{13}$.

Данный аргумент несостоятелен по двум причинам.

Во-первых, есть серьезные основания полагать, что вклад КрАЗа в загрязнение атмосферы города чрезвычайно опасными токсическими (канцерогенными) полициклическими ароматическими углеводородами (прежде всего бензапиреном) намного выше усредненных показателей. Целевой показатель КрАЗа по выбросам бензапирена, принятый на период до 2021 г. (500 кг в год), не позволит достичь требуемого снижения выбросов этого вещества (29 кг в год). Соответственно, без снижения мощности КрАЗа обеспечить необходимый уровень экологической безопасности в Красноярске нереально.

Во-вторых, возросшая острота экологических проблем в городе за счет ускоренного роста загрязнений от автотранспорта и «грязных» котельных и автономных источников теплообеспечения не отменяет проблем, связанных с загрязнениями КрАЗа,

Резолюция митинга «За чистое небо». г. Красноярск. 18 марта 2017 г. [Эл. pecypc]. URL: http://xn--80aclahh0bgeylld.xn--plai/ (дата обращения: 22.01.2018).

${ }^{12}$ Об экологической ситуации в городе Красноярске, неотложных и стратегических мерах по ее улучшению. Публичные слушания Законодательного собрани Красноярского края, 7 апреля 2016 г. [Эл. ресурc]. URL: http://www.sobranie.info/ hearings.php?UID=51950 (дата обращения: 22.01.2018).

${ }^{13}$ Ребрик И.И. Экология города: проблемы и пути их решения (презентация к выступлению на публичных слушаниях в Законодательном собрании Красноярского края 07.04.2016) [Эл. ресурc]. URL: http://www.sobranie.info/files/110416-32. pptx (дата обращения: 22.01.2018). который по-прежнему вносит существенный вклад в плохую экологию города.

Конечно, нужно подходить к проблеме улучшения создавшейся экологической ситуации в Красноярске комплексно и, наряду с мерами в отношении КрАЗа, проводить эффективную и действенную политику по всем направлениям (создание системы мониторинга и регулирования загрязняющих выбросов всех без исключения источников, переход на «чистые технологии» и т.д.). Однако решение проблемы КрАЗа (при всех вариантах) должно оставаться ключевым звеном экологической программы.

Аргумент 2. «РУСАЛ» находится на пороге создания революционной технологии «зеленого алюминия», который будет производиться с использованием инертных анодов. При этом алюминиевое производство из загрязнителя превратится в озонатор, вырабатывающий вместо углекислого газа кислород и улучшающий экологические характеристики воздуха в городе.

Не оспаривая суть прекрасной идеи, лидирующую мировую роль «РУСАЛа» в разработке соответствующих технологий и шансы на их воплощение в практику, следует отметить, что данная проблема находится в настоящее время на весьма далеких подступах к широкому промышленному применению. Сама по себе идея применения инертных анодов в электролизе алюминия с переменным успехом разрабатывается с 1980-х гг. как в стране, так и за рубежом, но пока не привела к реальным практическим результатам.

А потому делать миллионный город Красноярск заложником этой технологии (с неопределенными сроками промышленной реализации) неправильно. Для реализации идеи инертных анодов есть масса других возможностей - на вновь создаваемых предприятиях и в других регионах страны и мира.

Аргумент 3. Сокращение производства и вывод КрАЗа из Красноярска приведут к социальным проблемам, а также к снижению бюджетных доходов региона.

Приведем цитату из выступления генерального директора «РУСАЛа» В. Соловьева на пресс-конференции в рамках КЭФ-2017: «Перенос подразумевает, что в Красноярске мы завод сравняем с землей и построим его где-то в другом месте - в Богучанах, Тайшете, Хакасии. Эта площадка будет точно не здесь, если мы говорим о переносе, алюминиевого завода в Красноярске не будет. Мы хотим выкинуть 3,5 тысячи работников КрАЗа (заметим, что данные о численности работников КрАЗа, называемые генеральным директором «РУСАЛа", расходятся с данными, публикуемыми на официальном сайте 
«РУСАЛа» - 4200 чел. ${ }^{14}$ - Прим. авт.) плюс работников подрядных организаций вместе с семьями на улицу? Вот цена этого вопроса. Я уже не говорю про налоги, которые идут в край, не говорю об очереди в 1,6 тысяч человек из желающих работать у нас» ${ }^{15}$.

Во-первых, речь не идет об одномоментном сокращении численности занятых. Оно будет поэтапным - в течение 5-10 лет. Учитывая естественную текучесть кадров (около 4\% в год), связанную с выходом работников на пенсию по возрасту, личными мотивами и т.п., численность работающих завода может быть безболезненно сокращена на 20-40\%.

Во-вторых, сокращение объемов производства первичного алюминия будет сопровождаться созданием новых рабочих мест в прокатном производстве и углублением переработки первичного алюминия (проект «Технологическая (алюминиевая) долина Красноярска»). Часть работников КрАЗа после переподготовки может быть перемещена в эти производства.

В-третьих, по данным годовой финансовой отчетности КрАЗа за 2015-2016 гг, суммарный объем выплачиваемой КрАЗом оплаты труда (около 3 млрд руб. в год) и налоговые выплаты в региональные бюджеты (краевой и городской) (около 700800 млн руб. в год) существенно меньше присваиваемой КрАЗом ежегодной гидроэнергетической ренты (от 25 до 30 млрд руб.).

«Гидроэнергетическая рента - устойчивый в многолетнем разрезе экономический эффект, получаемый за счет использования гидроэнергетических ресурсов в региональной электроэнергетической системе и рассчитываемый как разность затрат на производство электроэнергии тепловыми конденсационными электростанциями, замыкающими энергобаланс данной электроэнергетической системы, и гидроэлектростанциями, использующими эти ресурсы» [Подковальников, 1997. С. 118].

Полное закрытие КрАЗа и возможность использования гидроэнергетической ренты другими потребителями региона обеспечат не только 100\%-ю компенсацию упущенных доходов (4 млрд руб.), но и создадут возможность получать дополнительно около 21-26 млрд руб.

${ }^{14}$ Соловьев В. РУСАЛ трудно упрекнуть в невнимании к экологии [Эл. ресурс] URL: http://www.dela.ru/articles/210293/ (дата обращения: 22.01.2018).

${ }^{15}$ Красноярский алюминиевый завод [Эл. ресурс]. URL: https://rusal.ru/about/41 (дата обращения: 22.01.2018).
Конечно, это лишь потенциальный ресурс. Для того чтобы он реально был получен, необходимы соответствующие механизмы и меры. Однако это вполне решаемая задача.

Аргумент 4. Сокращение объемов электролиза алюминия до 300-400 тыс. т снизит потребление электроэнергии Красноярской ГЭС на 10-12 млрд кВт•ч. Куда девать высвободившуюся электроэнергию?

Свободная энергия Красноярской ГЭС может быть направлена на покрытие потенциального дефицита электрической мощности в связи с формированием Ангаро-Енисейского кластера.

Инвестиционный проект Ангаро-Енисейского кластера имеет высокую народнохозяйственную и региональную эффективность ${ }^{16}$ :

- обеспечивает сокращение безработицы, привлечение и закрепление нового населения путем организации и сохранения 6,5 тыс. новых постоянных рабочих мест;

- обеспечивает до 54\% прироста ВРП Красноярского края и до 1,3\% прироста ВВП Российской Федерации;

- позволяет увеличить суммарный объем налоговых отчислений в федеральный бюджет на 13,9 млрд руб. в год;

- позволяет увеличить суммарный объем налоговых отчислений в консолидированный бюджет Красноярского края на 12,9 млрд руб. в год.

Реализация проекта (наряду с другими факторами) сдерживается потенциальным дефицитом электрической энергии в зоне его реализации, который оценивается в размере до 1000 МВт энергетической мощности (7 млрд кВт·ч электроэнергии в год).

Используя свободные мощности Красноярской ГЭС, можно сэкономить затраты на строительство предполагаемой Нижнеангарской ГЭС (86 млрд руб. в ценах 2012 г.) и избежать острых экологических вопросов, связанных с воздействием данного объекта на окружающую природную среду в зоне затопления.

Таким образом, поэтапное сокращение мощности КрАЗа и кардинальная модернизация оставшихся электролизеров с использованием самых современных и прогрессивных технологий позволит не только решить экологические проблемы

\footnotetext{
${ }^{16}$ Бизнес-план комплексного инвестиционного проекта «Ангаро-Енисейский кластер» //Корпорация развития Красноярского края. Государственный контракт от 23.07.2012 № 01/07-2012.
} 
Красноярска, но и снизит экологическую нагрузку на Ангару и зону реализации инвестиционного проекта Ангаро-Енисейского кластера.

Отказ от строительства Нижне-Ангарской ГЭС позволит сохранить естественное русло Ангары со свободным водообменом на расстоянии до 500 км от устья. В случае реализации проекта Нижне-Ангарской ГЭС, водообмен в каскаде Ангарских водохранилищ (Братское, Усть-Илимское, Богучанское, Нижне-Ангарское) снизится в несколько раз по сравнению с естественным водотоком в реке Ангара, река превратится в самое крупное на планете рукотворное «болото», что кардинально ухудшит экологические условия не только населения Нижнеангарского кластера, но и приведет к утрате таежного биоразнообразия в пойме Ангары.

\section{Подведем итоги}

1. При проектировании и строительстве КрАЗа были допущены ошибки, из-за которых возникли следующие экологические проблемы:

- сверхвысокая концентрация электролизного производства вблизи крупного населенного пункта;

- использование неэффективных технологических решений на основе самообжигающихся анодов и несовершенной системы очистки отходящих газов.

За пятьдесят лет функционирования предприятия экологические проблемы проекта только усугубились - мощность КрАЗа возросла с 800 тыс. т до 1 млн т, а производственная площадка завода с окраины переместилась в административные границы города.

Масштабная экологическая модернизация и замена устаревшей технологии электролиза на более эффективную с использованием коллоидных анодов («ЭкоСодерберг»), а также целый ряд других прогрессивных изменений позволили добиться существенных улучшений экологических характеристик предприятия. Однако снизить масштабы негативного воздействия на окружающую среду до нормативных уровней так и не удалось. КрАЗ остается и в обозримой перспективе будет оставаться крупнейшим загрязнителем г. Красноярска и Красноярской агломерации. Особенно острые проблемы КрАЗа связаны с загрязнением атмосферного воздуха опасными выбросами, прежде всего токсином 1-й категории опасности - бензапиреном. Даже после полного перехода завода на технологию «ЭкоСодерберг» нормативные показатели по выбросам бензапирена будут превышены в 18-20 раз.

2. Деятельность КрАЗа характеризуется низкой региональной социально-экономической эффективностью. Доходы, генерируемые и локализуемые КрАЗом на территории Красноярска (оплата труда, платежи в бюджет и местные фонды, финансирование социальных программ) существенно меньше аккумулируемой предприятием гидроэнергетической ренты (устойчивой разности затрат на производство относительно более дешевой энергии Красноярской ГЭС и более дорогой электроэнергии, вырабатываемой тепловыми конденсационными электростанциями). Разница локализуемых доходов и гидроэнергетической ренты складывается не в пользу региональных доходов и составляет (по оценкам) 21-26 млрд руб. в год.

3. Алюминиевая промышленность Сибири является одним из наиболее приоритетных секторов развития российской экономики. «РУСАЛ», использующий важное конкурентное преимущество - дешевую гидроэлектроэнергию сибирских ГЭС - имеет все предпосылки к тому, чтобы оставаться крупнейшим в мире производителем алюминия.

Вместе с тем, получение «РУСАЛом» конкурентных преимуществ на мировом и российском рынках алюминия не должно вступать в противоречие с интересами сбалансированного устойчивого социально-экономического развития территорий, где компания ведет свою производственную деятельность. Пример КрАЗа является свидетельством подобных нарушений и противоречий.

Для устранения этих противоречий необходимо разработать и реализовать стратегию поэтапного сокращения производственных мощностей предприятия (до 300-400 тыс. т); обеспечить модернизацию базовых технологических процессов и повысить уровень их экологической безопасности; создать широкую сеть предприятий, перерабатывающих алюминий; повысить прозрачность и публичность деятельности и отчетности.

4. Свободные ресурсы Красноярской ГЭС, образовавшиеся в результате снижения мощности Красноярского алюминиевого завода, позволят обеспечить электроэнергией формирующийся 
Ангаро-Енисейский территориально-производственный кластер. Это приведет к повышению эколого-экономической эффективности региональной экономики за счет экономии средств на строительство новой ГЭС и снижения экологической нагрузки на окружающую среду в Нижнем Приангарье.

\section{Литература}

Алюминиевая промышленность России в рыночных условиях/ Под ред. ак. В. В. Кулешова. Новосибирск: ИЭиОПП, 1997.

Подковальников C.B. Методические и прикладные аспекты экономической оценки гидроэнергетических ресурсов и определение платежей за их использование // Становление рыночной экономики в России. М.: НИУ ВШЭ. 1997. C. $111-137$.

Экологический паспорт Красноярского алюминиевого завода Минцветмета СССР //Академия наук СССР, Красноярский научный центр /Общ. ред. А.Г. Аншиц, А. В. Кучеренко, Г.П. Курышева. Красноярск, 1989.

Статья поступила 08.02.2018.

\section{Summary}

Sibgatulin V.G., NP ROPR Ecological Center, Krasnoyarsk

Shishatsky N.G., Institute of Economics and Industrial Engineering of SB RAS, Krasnoyarsk

\section{Krasnoyarsk Aluminium Smelter: ecological factor}

The article considers a factors and parameters of impact of the Krasnoyarsk Aluminium Smelter on the environment of the city of Krasnoyarsk. It is shown that, despite realization of large-scale measures for ecological modernization, the enterprise remains and, in the foreseeable future, will remain the largest pollutant of the city of Krasnoyarsk. Offers on decrease in negative ecological impact and increase in regional economic overall performance of the enterprise are made.

Pollution of atmospheric air; ecological modernization; the best available technologies; aluminum electrolysis; regional economic efficiency

\section{References}

Aljuminievaja promyshlennost' Rossii v rynochnyh uslovijah/ Pod red. ak. V.V. Kuleshova. Novosibirsk. IJeiOPP, 1997. (In Russ.).

Podkoval'nikov S.V. (1997) Metodicheskie i prikladnye aspekty jekonomicheskoj ocenki gidrojenergeticheskih resursov i opredelenie platezhej za ih ispol'zovanie. Jn: Stanovlenie rynochnoj jekonomiki v Rossii. Moscow, NIU VShJe. Rubl. Pp. 111-137. (In Russ.).

Ekologicheskij pasport Krasnojarskogo aljuminievogo zavoda Min-cvetmeta SSSR. Akademija nauk SSSR, Krasnojarskij nauchnyj centr. Obshh. red. A. G. Anshic, A. V. Kucherenko, G. P. Kurysheva. Krasnojarsk, 1989. (In Russ.).

\section{«ЭКО»-информ}

3 марта 2018 г. в Красноярске прошло совещание, посвященное разработке комплексной программы оздоровления экологии города. Министр природных ресурсов и экологии РФ Сергей Донской и врио губернатора края Александр Усс пригласили на встречу руководителей федеральных и краевых ведомств, контролирующих органов, а также представителей крупнейших компаний, работающих на территории края.

Комплексная программа будет включать несколько направлений - от модернизации систем теплоснабжения и муниципального транспорта до введения особого режима работы больших городских производств в период неблагоприятных метеоусловий. Крупные предприятия обязались продолжить реализацию программ по модернизации оборудования, переходу на экологичные технологии, снижению выбросов, кроме того, их напрямую коснется программа совершенствования системы мониторинга загрязнения атмосферного воздуха: данные мониторинга предприятий будут интегрированы в общую систему государственной сети наблюдений Среднесибирского УГМС и территориальной сети мониторинга.

Сергей Донской подчеркнул, что решение задач в сфере экологии требует системного подхода: «Сегодня речь идет не только о производстве и энергетике, но и о транспорте, о градостроительной политике».

В свою очередь Александр Усс отметил, что в Красноярске уже разработана предварительная карта действий для оздоровления экологии, хотя совершенно очевидно, что усилий только одного Красноярска, с учетом ограниченности финансовых ресурсов, а также административных рычагов воздействия, для этого не хватит. Все же он выразил надежду, что «при активном участии всех заинтересованных сторон и серьезном внимании президента к этой теме двух-трех лет будет достаточно, чтобы добиться в сфере экологии впечатляющих результатов».

Напомним, что в своем Послании Федеральному собранию от 2 марта 2018 г. Президент РФ Владимир Путин заявил, что к 2019 г. 300 российских предприятий, оказывающих наиболее значительное негативное воздействие на окружающую среду, должны перейти на самые лучшие доступные технологии и новые 
экологические стандарты. А к 2021 г. к новым стандартам, по его словам, должны подключиться все предприятия повышенного экологического риска. Президент особо подчеркнул, что переноситься эти сроки не будут.

По данным Минприроды, в 2017 г. четыре города Красноярского края (Норильск, Лесосибирск, Минусинск и сам Красноярск) вошли в первую двадцатку городов России с наибольшим уровнем загрязнения атмосферы.

В рамках рабочей поездки в Красноярск в марте 2018 г. глава Минприроды Сергей Донской посетил Красноярский алюминиевый завод, где ему рассказали о реализации экологической программы предприятия, реализуемой с 2004 г. За это время завод почти вдвое снизил выбросы загрязняющих веществ. Актуальные проекты рассчитаны до 2021 г. Среди них перевод мощностей на новую, более экологичную технологию производства алюминия, внедрение несгораемого (коллоидного) анода с более низким уровнем смолистых веществ, переработка отходов, модернизация системы экомониторинга.

Источник: по материалам СМИ. 